Review

\title{
Use of non-hyperaccumulator plant species for the phytoextraction of heavy metals using chelating agents
}

\author{
Lucas Anjos Souza ${ }^{1}$, Fernando Angelo Piotto², Roberta Corrêa Nogueirol², Ricardo Antunes Azevedo*
}

'UNICAMP/Instituto de Biologia - Depto. de Biologia Vegetal, C.P. 6109 - 13083-970 - Campinas, SP - Brasil.

2USP/ESALQ - Depto. de Genética, C.P. 83 - 13418-900 -

Piracicaba, SP - Brasil.

*Corresponding author <raa@usp.br>

Edited by: Daniel Scherer de Moura
ABSTRACT: Soil contamination by heavy metals is a challenge faced by many countries, and engineering technologies to solve this problem are expensive and can cause negative impacts on the environment. One way to minimise the levels of heavy metals in the soil is to use plants that can absorb and accumulate heavy metals into harvestable parts, a process called phytoextraction. Typical plant species used in research involving phytoextraction are heavy metal hyperaccumulators, but plants from this group are not good biomass producers and grow more slowly than most species; thus, they have an important role in helping scientists understand the mechanisms involved in accumulating high amounts of heavy metals without developing symptoms or dying. However, because of their slow growth, it is not practical to use these species for phytoextraction. An alternative approach is to use non-hyperaccumulator plants assisted by chelating agents, which may improve the ability of plants to accumulate more heavy metals than they would naturally. Chelating agents can be synthetic or organic acids, and the advantages and disadvantages of their use in improving the phytoextraction potential of non-hyperaccumulator plants are discussed in this article. We hope to draw attention to ways to improve the phytoextraction potential of non-hyperaccumulator plants that produce a large amount of biomass and to stimulate more research on phytoextraction-inducing substances.

Received October 17, 2012

\section{Introduction}

The contamination of the environment is a major global problem that has been widely reported, and different types of contaminants predominate in different parts of the world, with some causing more damage than others (Gratão et al., 2005; Garcia et al., 2006; Ghelfi et al., 2011; Monteiro et al., 2011; Gratão et al., 2012). There is a wide range of pollutants, and it is unsurprising that due to their nature, specifically their chemical makeup, different strategies must be used to remediate a contaminated area. Remediation techniques, such as bioremediation and phytoremediation, were introduced several years ago and they have long been considered promising techniques, with specific approaches having received substantial analysis. Phytoremediation is now widely accepted and employed in some countries. Detailed review papers on remediation techniques are available (Dickinson et al., 2009; Dhankher et al., 2012; Zhu et al., 2012); thus, the goal of the present review is to specifically address the use of non-hyperaccumulator plant species for the phytoextraction of heavy metals from soil.

\section{Phytoremediation}

Heavy metal contamination of soils is an important environmental issue because of its impact on soil preservation and human health (Li et al., 2005). In São Paulo State, Brazil, 4,131 contaminated sites have been identified, and 543 of them are contaminated with a variety of metals (CETESB, 2011). Phytoremediation is an environmentally friendly and safe technique that em- ploys the use of plants to recover/clean polluted soils, particularly those polluted with heavy metals or toxic organic compounds (Gratão et al., 2005). Engineering techniques such as soil washing, burning, excavation and removal are used to remediate heavy-metal-contaminated soils, but the cost of these procedures is very high (Pilon-Smits, 2005). For this reason, the development of low-cost, effective, and sustainable technologies to remediate heavy-metal-contaminated soils is very important and long overdue (LeDuc and Terry, 2005), and it should receive considerably more attention.

The phytoremediation process can be divided into different classes (Pilon-Smits, 2005): (i) phytostabilisation - the contaminant remains complexed in root tissues, thus being unable to move through the soil; (ii) phytostimulation/rhizodegradation - the contaminant, generally organic, is degraded by rhizosphere-specific microorganisms; (iii) phytovolatilisation - the contaminant (inorganic or organic), once absorbed, is physically changed to a gaseous state by the plant's metabolism; (iv) phytodegradation - similar to phytostimulation/ rhizodegradation but occurring in the aerial parts of the plant; $(\mathrm{v})$ phytoextraction - the contaminant is absorbed, and high concentrations are transported to the aerial parts of the plant, making it possible to harvest the aboveground plant parts containing the contaminant (Figure 1).

The transfer factor is used to measure how much metal moves from soil to plant tissues/organs (Sauerbeck, 1991), and the translocation index measures how much of the metal taken up is transported to the aboveground 


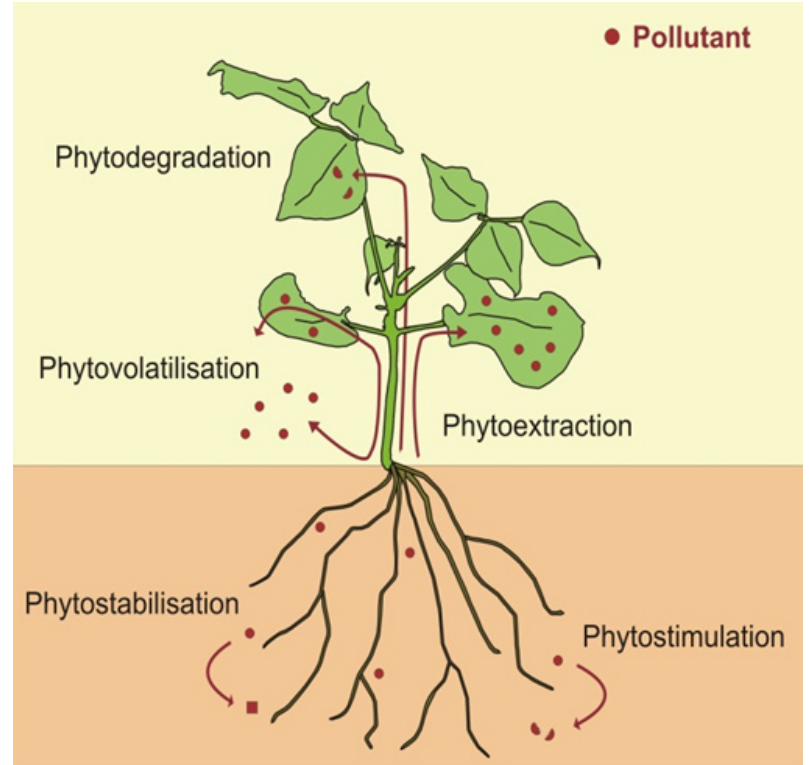

Figure 1 - Schematic representation of possible fates of pollutants during the phytoremediation processes. Figure adapted from (Pilon-Smits, 2005).

plant parts (de Abreu et al., 2012). These numerical factors are used to assess the phytoextraction potential of a plant species. The choice of the method employed and its application should take into account the type of contaminant, the type of environment and the amount of the contaminant that is available to the plant; another important aspect is the interaction between the plant and the soil microorganisms, such as bacteria and mycorrhizae. The benefits of these interactions have already been demonstrated (Andrade et al., 2009; Andrade et al., 2010; Khan and Doty, 2011; Luo et al., 2011). The impact of heavy metal exposure on nodule formation and nitrogen fixation in leguminous plants is another important issue that requires more study, with little information available (Matsuda et al., 2002; Obbard and Jones, 2001; Reichman, 2007). Information about Rhizobium behaviour under heavy metal stress is also important and might provide key information to improve phytoremediation if these symbioses can be established under stressful conditions.

\section{Hyperaccumulator and non-hyperaccumulator} plant species: advantages and disadvantages

The fundamental question is: What plant species should be used for phytoremediation? The answer appears to be those species that are able to accumulate higher amounts of heavy metals in the aboveground parts, which have been designated as hyperaccumulators; the classic example is Noccaea caerulescens (J. Presl \& C. Presl) F. K. Mey (formerly Thlaspi caerulescens) (Prayon) (Monsant et al., 2011), a Brassicaceae hyperaccumulator of zinc (Zn) (Baker et al., 1994).
The factors that allow for the characterisation of a plant species as a hyperaccumulator species depend on the heavy metal being accumulated. According to Krämer (2010), heavy metal concentrations in aerial parts varying from 1,000 to $10,000 \mathrm{mg} \mathrm{kg}^{-1}$ in plant shoots, depending on the metal, are typically a good indicator of a hyperaccumulator plant species. In the case of cadmium $(\mathrm{Cd})$, the concentration is considerably lower (100 mg kg-1) (Krämer, 2010) because of the high toxicity of this metal. Another criterion, developed by Baker et al. (1994), takes into consideration the element concentration ratio between aerial parts and roots, where a ratio above 1.0 indicates that the contaminant is mainly accumulated in aerial parts, which means it is a hyperaccumulator and might be suitable for phytoextraction. Nevertheless, whichever parameter is selected to classify a species as a hyperaccumulator, the focus is on the plant's ability to transport/translocate and accumulate large amounts of the metal into the aerial parts of the plant, making it possible to harvest and process the plant material.

Thus far, the majority of the plant species classified as hyperaccumulators fulfil the criteria described above. These species, however, produce little biomass and are slow-growing plants, which makes it unfeasible to use these species in phytoremediation. Nonetheless, these model organisms, which are able to accumulate extremely high concentrations of heavy metals, have been essential for studies focused on understanding the mechanisms that allow them to accumulate and tolerate phytotoxic concentrations of a wide range of heavy metals. Thus, these organisms can be used as a reference from which to develop strategies to genetically modify other plant species that have more favourable characteristics for phytoextraction, such as higher biomass production. For this reason, non-hyperaccumulator plant species should be studied for their phytoremediation potential to be understood, particularly crop plant species that have high biomass production (Peuke and Rennenberg, 2005) and are tolerant of other abiotic factors. Additional factors to consider include good growth performance in the field, little investment needed for pest management and the possibility of using mechanised harvesting methods for collecting aboveground plant parts.

Not only crop plant species should be considered, but non-hyperaccumulator woody plant species, such willow, poplar (Zacchini et al., 2009) and Brazilian leguminous trees (Mimosa caesalpiniaefolia, Erythrina speciosa and Schizolobium parahyba) (de Souza et al., 2012a), should also be investigated. These woody species has been studied with special attention to their phytoremediation capability in the recovery of areas contaminated with lead $(\mathrm{Pb})$ (de Souza et al., 2012a). Such plant species possess an enormous plant biomass, and the accumulation of heavy metals taken up from the soil in such a large biomass would be significant and warrant the immobilisation of metal in the aboveground parts of the tree. 
Plant species such as sunflower (Helianthus annuus L.), jack bean (Canavalia ensiformis L.), velvet bean (Stizolobium aterrimum L.), castor bean (Ricinus communis L.) and others have been extensively exploited for their heavy metal tolerance and phytoremediation potential (Adhikari and Kumar, 2012; de Andrade et al., 2005; de Andrade et al., 2008; de Souza et al., 2011; Giordani et al., 2005; Ullah et al., 2011). Studies with these plant species have been carried out in hydroponic systems under greenhouse conditions to better understand the patterns of response, distribution and accumulation of heavy metals. As the plant's response to heavy metals may vary depending on the soil type due to differences in metal bioavailability with soil type (Melo et al., 2011), any subsequent use of a species must be confirmed in an experimental system modelled after realworld conditions to test the plant's performance in an actual decontamination situation. In addition, the biotic and abiotic factors that can influence metal availability to the plant must be properly considered and addressed (Basta et al., 2005).

Non-hyperaccumulator plant species can be used in phytoremediation (Andrade et al., 2010; de Souza et al., 2012b); despite the fact that these species do not accumulate high concentrations of metal, their biomass production overcomes by several orders of magnitude the capability of typical hyperaccumulator plant species. Therefore, the total metal extraction can be higher in non-hyperaccumulator than in hyperaccumulator plant species because of the relationship between metal accumulation in aerial parts and the growth potential of these species.

\section{Improving the phytoextraction potential of non- hyperaccumulator plant species}

In this section, we will discuss a technique that is able to improve the phytoextraction potential of nonhyperaccumulator plant species, which involves the application of chelating compounds in a process that has been named chelate-assisted phytoextraction or, simply, induced phytoextraction (Salt et al., 1998). These processes can be divided into two groups depending on the chelating agent type: synthetic chelating agents or organic chelate agents, which are normally organic acids.

\section{Synthetic chelating agents}

Some synthetic chelating agents, such as ethylene diamine tetraacetic acid (EDTA), diethylene triamine pentaacetic acid (DTPA) and ethylene glycol tetraacetic acid (EGTA) have been used successfully for induced phytoextraction (Pereira et al., 2010). However, the application of such synthetic chelating agents introduces an environmental risk due to their high mobility in the soil, which can result in the transport of the contaminant to uncontaminated surrounding areas; this movement can potentially become a problem due to the high solubility and persistence in the soil of the chelate-heavy metal complex (Luo et al., 2006; Quartacci et al., 2007).
Another important consideration for the application of synthetic chelates is that it may exceed heavy metal uptake by the plant, thus becoming a risk for increased toxicity for the plants (do Nascimento et al., 2006a). Furthermore, beyond the application of the chelating agent, many other factors, such as temperature, soil $\mathrm{pH}$ and aeration, Eh condition, fertilisation, competition between plant species, the size of the plant and the structure of its root system, may influence metal availability in the environment (Yamamoto and Kozlowski, 1987). Thus, absorption depends on the amount of metal in the soil as well as the element's binding strength in the soil and the plant's ability to regulate the uptake of the element (Smith, 2009). Seth et al. (2011) demonstrated that the application of EDTA together with lead $(\mathrm{Pb})$ increased the amount of $\mathrm{Pb}$ accumulated by more than $80 \%$ in the aboveground parts of sunflower plants cultivated in hydroponic system. Kos et al. (2003) also demonstrated that EDTA application promoted the accumulation of $\mathrm{Pb}, \mathrm{Cd}$ and $\mathrm{Zn}$ in several plant species from different families, including Cannabis sativa, Medicago sativa, Zea mays and Sorghum vulgare.

Despite the improvement in absorption from the application of chelating agents, the potential problem of contaminants leaching into uncontaminated areas remains, and further research is needed to understand the size and significance of these risks in each situation. Special attention should be paid to research on alternative methods to induce phytoextraction by non-hyperaccumulator plant species without introducing any extra risk or damage to the environment.

\section{Organic chelating agents}

In contrast to the use of high-cost synthetic chelating agents, an interesting alternative based on the same concept of induced phytoextraction is the use of natural organic chelating agents, also called low-molecularweight organic acids (LMWOA), such as citric acid, oxalic acid, malic acid and acetic acid. These molecules can form complexes of low to moderate stability with metals. Sun et al. (2006) reported citrate and acetate to be $\mathrm{Cd}$ ligands in the Cd-hyperaccumulator Solanum nigrum. Krämer et al. (2000) also found citrate to be a Ni ligand in the leaves of Thlaspi goesingense, and Sarret et al. (2002) found malate to be a Zn ligand in Thlaspi caerulescens, indicating the formation of complexes among organic acids and metals.

LMWOA present an advantage because of their high rate of biodegradation in the soil (do Nascimento et al., 2006a; Quartacci et al., 2005), which means they do not cause the negative effects potentially caused by the application of the synthetic chelating compounds. In addition, the toxicity effect on plants, such as growth reduction, is not observed when citric acid is applied, in contrast to EDTA (Evangelou et al., 2006). The excellent reports from do Nascimento et al. (2006a) and Freitas et al. (2009) showed the efficiency of the application of organic acids as phytoextraction assistants for a wide range of heavy metals, recom- 
mending the use of organic acids rather than the more toxic EDTA (do Nascimento, 2006b). Additionally, acidity should be considered because the bioavailability of the metal is a key issue for phytoremediation techniques. Although acidity does not act as a chelating agent, Komárek et al. (2008) reported the potential of $\mathrm{NH}_{4} \mathrm{Cl}$ to be a hydrolysing acidic salt with a volatile cation constituent (ammonium).

It is essential to assess the heavy metal tolerance of crop plant species using treatments with compounds that are able to induce phytoextraction and that facilitate the uptake of heavy metals by non-hyperaccumulator plant species. The use of phytoextraction-stimulating substances for non-hyperaccumulator plant species is necessary because the patterns of heavy metal uptake and accumulation are different between hyperaccumulator and non-hyperaccumulator plant species (Figure $2 \mathrm{~A}$ and B). It is also important for these organic chelating compounds to be applied close to the harvesting stage (Figure $2 \mathrm{~B}$ ) because a key aspect of this approach is that organic acids are carbon sources for soil microorganisms; thus, their action time in the soil is relatively short but highly effective. Furthermore, Qin et al. (2004) reported that the use of LMWOA favoured the desorption of $\mathrm{Cu}, \mathrm{Cd}$ and $\mathrm{Pb}$ from the soil, making these metals more available to the plants.

The phytoextraction process occurs during the vegetative growth stage, during which biomass production and accumulation is more intense, thus favouring the absorption of the contaminant elements available in the soil. Thus, it is essential to maximise the contaminant transport from the root system to the aboveground parts of the plant for the phytoextraction process be more effective (Bhargava et al., 2012). Induced phytoextraction has not been applied to the extent we believe it should have been. Additionally, studies can identify crops with multiple uses if the contaminants do not accumulate in edible parts of the plants. Following along with this approach, it is necessary to conduct an initial plant screening to evaluate the responses of the plants to several heavy metals with the
A

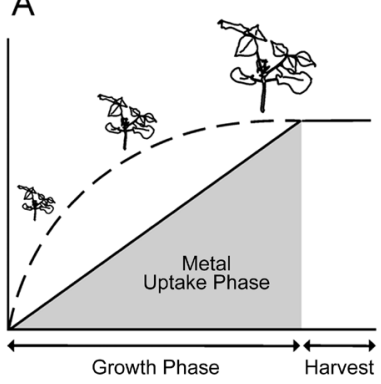

B

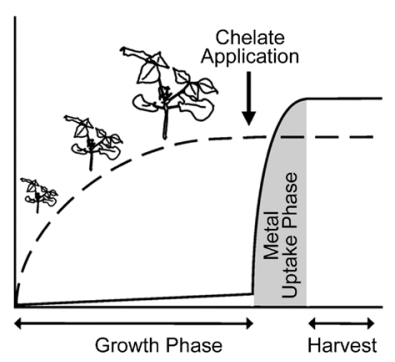

Figure 2 - Schematic behaviour diagram of a hyperaccumulator plant (A) and a non-hyperaccumulator plant (B). In example (A), heavy metal accumulation is gradual and constant during the entire life cycle of the plant, whereas in example (B), heavy metal uptake is slow, but after chelate application, the heavy metal uptake increases rapidly. Figure adapted from Salt et al. (1998). goal of determining which heavy metals the crop plant species can tolerate and which heavy metals are more successfully taken up by the plant, bringing new insights to crop breeding. Once the plant's behaviour and patterns of heavy metal accumulation are determined, trials with different organic acids in different types of soils should be carried out to determine the best growth stage during which to apply organic chelating agents as well as the most appropriate amount of chelating agent to cause the highest accumulation of the desired heavy metal. In addition, each plant species should be considered in its natural habitat so that it can maintain their natural growth and developmental patterns.

\section{Final considerations}

Phytoremediation is a technique with a low cost of implementation and maintenance that is used commercially in countries such as the United States and Canada, but in Brazil, it is still not used and is currently restricted solely to laboratory and greenhouse trials. Therefore, it is necessary to draw attention to methods focused on improving the efficiency of non-hyperaccumulator plant species for use in the induced-phytoextraction process, which has tremendous potential and advantages. With greater diffusion of this technique, field trials and experiments can be carried out to examine the real potential for its use, and promising results for the remediation of heavy metals in contaminated areas may be obtained.

\section{Acknowledgements}

This work was funded by Fundação de Amparo à Pesquisa do Estado de São Paulo (FAPESP - Grant $\mathrm{n}^{\mathrm{o}}$. 09/54676-0) and by the Conselho Nacional de Desenvolvimento Científico e Tecnológico $/ \mathrm{CNPq} \mathrm{n}^{\circ}$. 477652/2010-7). The first author thanks FAPESP for the scholarship, Process no 2010/50167-0.

\section{References}

Adhikari, T.; Kumar, A. 2012. Phytoaccumulation and tolerance of Riccinus communis L. to nickel. International Journal of Phytoremediation 14: 481-492.

Andrade, S.A.L.; Gratão, P.L.; Schiavinato, M.A.; Silveira, A.P.; Azevedo, R.A.; Mazzafera. P. 2009. Zn uptake, physiological response and stress attenuation in mycorrhizal jack bean growing in soil with increase $\mathrm{Zn}$ concentration. Chemosphere 75: 1363-1370.

Andrade, S.A.L.; Gratão, P.L.; Azevedo, R.A.; Silveira, A.P.D.; Schiavinato, M.A.; Mazzafera, P. 2010. Biochemical and physiological changes in jack bean under mycorrhizal symbiosis growing in soil with increasing $\mathrm{Cu}$ concentrations. Environmental and Experimental Botany 68: 198-207.

Baker, A.J.M.; Reeves, R.D.; Hajar, A.S.M. 1994. Heavy metal accumulation and tolerance in British populations of the metallophyte Thlaspi caerulescens J. \& C. Presl (Brassicaceae). New Phytologist 127: 61-68. 
Basta, N.T.; Ryan, J.A.; Chaney, R.L. 2005. Trace element chemistry in residual-treated soil: key concepts and metal bioavailability. Journal of Environmental Quality 34: 49-63.

Bhargava, A.; Carmona, F.F.; Bhargava, M.; Srivastava, S. 2012. Approaches for enhanced phytoextraction of heavy metals. Journal of Environmental Management 105: 103-120.

Companhia de Tecnologia de Saneamento Ambiental [CETESB]. 2011. Texto explicativo: Relações de áreas contaminadas e reabilitadas no Estado de São Paulo = Explanatory text: List of contaminated and recovered areas in São Paulo State. Available in: http://www.cetesb.sp.gov.br/userfiles/file/areascontaminadas/2011/texto-explicativo.pdf. [Accessed Dec. 21, 2012]

de Abreu, C.A.; Coscione, A.R.; Pires, A.M.; Paz-Ferreiro, J. 2012. Phytoremediation of a soil contaminated by heavy metals and boron using castor oil plants and organic matter amendments. Journal of Geochemical Exploration 123: 3-7.

de Andrade, S.A.L.; Jorge, R.A.; da Silveira, A.P.D. 2005. Cadmium effect on the association of jackbean (Canavalia ensiformis) and arbuscular mycorrhizal fungi. Scientia Agricola 62: 389-394.

de Andrade, S.A.L.; da Silveira, A.P.D.; Jorge, R.A.; de Abreu, M.F. 2008. Cadmium accumulation in sunflower plants influenced by arbuscular mycorrhiza. International Journal of Phytoremediation 10: 1-14.

de Souza, L.A.; de Andrade, S.A.L.; de Souza, S.C.R.; Schiavinato, M.A. 2011. Tolerance and phytoremediation potential of Stizolobium aterrimum associated to the arbuscular mycorrhizal fungi Glomus etunicatum in lead-contaminated soil. Revista Brasileira de Ciência do Solo 35: 1441-1451 (in Portuguese, with abstract in English).

de Souza, L.A.; de Andrade, S.A.L.; de Souza, S.C.R.; Schiavinato, M.A. 2012a. Arbuscular mycorrhiza confers Pb tolerance in Calopogonium mucunoides. Acta Physiologiae Plantarum 34: 523-531.

de Souza, S.C.R.; de Andrade, S.A.L.; de Souza, L.A.; Schiavinato, M.A. 2012b. Lead tolerance and phytoremediation potential of Brazilian leguminous tree species at the seedling stage. Journal of Environmental Management 110: 299-307.

Dhankher, O.P.; Pilon-Smits, E.A.H.; Meagher, R.B.; Doty, S. 2012. Biotechnological approaches for phytoremediation. p. 309-328. In: Altman, A.; Hasegawa, P.M., eds. Plant biotechnology and agriculture. Academic Press, San Diego, CA, USA.

Dickinson, N.M.; Baker, A.J.M.; Doronila, A.; Laidlaw, S.; Reeves, R.D. 2009. Phytoremediation of inorganics: realism and synergies. International Journal of Phytoremediation 11: 97-114.

do Nascimento, C.W.A.; Amarasiriwardena, D.; Xing, B.S. 2006 a. Comparison of natural organic acids and synthetic chelates at enhancing phytoextraction of metals from a multi-metal contaminated soil. Environmental Pollution 140: 114-123.

do Nascimento, C.W.A. 2006b. Organic acids effects on desorption of heavy metals from a contaminated soil. Scientia Agricola 63: 276-280.

Evangelou, M.W.H.; Ebel, M.; Schaeffer, A. 2006. Evaluation of the effect of small organic acids on phytoextraction of $\mathrm{Cu}$ and $\mathrm{Pb}$ from soil with tobacco Nicotiana tabacum. Chemosphere 63: 996-1004.
Freitas, E.V.D.; do Nascimento, C.W.A.; Silva, A.J.; Duda, G.P. 2009. Citric acid enhances lead phytoextraction from a soil contaminated by automotive batteries. Revista Brasileira de Ciência do Solo 33: 467-473 (in Portuguese, with abstract in English).

Garcia, J.S.; Gratão, P.L.; Azevedo, R.A.; Arruda, M.A.Z. 2006. Metal contamination effects on sunflower (Helianthus annuus L.) growth and protein expression in leaves during development. Journal of Agricultural and Food Chemistry 54: 8623-8630.

Ghelfi, A.; Gaziola, S.A.; Cia, M.C.; Chabregas, S.M.; Falco, M.C.; Kuser-Falcão, P.R.; Azevedo, R.A. 2011. Cloning, expression, molecular modelling and docking analysis of glutathione transferase from Saccharum officinarum. Annals of Applied Biology 159: 267-280.

Giordani, C.; Cecchi, S.; Zanchi, C. 2005. Phytoremediation of soil polluted by nickel using agricultural crops. Environmental Management 36: 675-681.

Gratão, P.L.; Prasad, M.N.V.; Cardoso, P.F.; Lea, P.J.; Azevedo, R.A. 2005. Phytoremediation: green technology for the clean up of toxic metals in the environment. Brazilian Journal of Plant Physiology 17: 53-64.

Gratão, P.L.; Monteiro, C.C.; Carvalho, R.F.; Tezotto, T.; Piotto, F.A.; Peres, L.E.P.; Azevedo, R.A. 2012. Biochemical dissection of diageotropica and Never ripe tomato mutants to Cd-stressful conditions. Plant Physiology and Biochemistry 56: 79-96.

Khan, Z.; Doty, S. 2011. Endophyte-assisted phytoremediation. Current Topics in Plant Biology 12: 97-105.

Komárek, M.; Tlustos, P.; Szakova, J.; Chrastny, V. 2008. The use of poplar during a two-year induced phytoextraction of metals from contaminated agricultural soils. Environmental Pollution 151: 27-38.

Kos, B.; Grcman, H.; Lestan, D. 2003. Phytoextraction of lead, zinc and cadmium from soil by selected plants. Plant Soil and Environment 49: 548-553.

Krämer, U. 2010. Metal Hyperaccumulation in Plants. Annual Review of Plant Biology 61: 517-534.

Krämer, U.; Pickering, I.J.; Prince, R.C.; Raskin, I.; Salt, D.E. 2000. Subcellular localization and speciation of nickel in hyperaccumulator and non-accumulator Thlaspi species. Plant Physiology 122: 1343-1353.

LeDuc, D.L.; Terry, N. 2005. Phytoremediation of toxic trace elements in soil and water. Journal of Industrial Microbiology \& Biotechnology 32: 514-520.

Li, H.; Wang, Q.; Cui, Y.; Dong, I.; Christie, P. 2005. Slow release chelate enhancement of lead phytoextraction by corn (Zea mays L.) from contaminated soil - a preliminary study. The Science of the Total Environment 339: 179-187.

Luo, C.; Shen, Z.; Li, X.; Baker, A.J.M. 2006. Enhanced phytoextraction of $\mathrm{Pb}$ and other metals from artificially contaminated soils through the combined application of EDTA and EDDS. Chemosphere 63: 1773-1784.

Luo, S.L.; Chen, L.; Chen, J.L.; Xiao, X.; Xu, T.Y.; Wan, Y.; Rao, C.; Liu, C.B.; Liu, Y.T.; Lai, C.; Zeng, G.M. 2011. Analysis and characterization of cultivable heavy metal-resistant bacterial endophytes isolated from Cd-hyperaccumulator Solanum nigrum L. and their potential use for phytoremediation. Chemosphere 85: $1130-1138$. 
Matsuda, A.; Moreira, F.M.S.; Siqueira, J.O. 2002. Tolerance of rhizobia genera from different origins to zinc, copper and cadmium. Pesquisa Agropecuária Brasileira 37: 343-355 (in Portuguese, with abstract in English).

Melo, L.C.A.; Alleoni, L.R.F.; Carvalho, G.; Azevedo, R.A. 2011. Cadmium- and barium-toxicity effects on growth and antioxidant capacity of soybean (Glycine max L.) plants, grown in two soil types with different physicochemical properties. Journal of Plant Nutrition and Soil Science 174: 847-859.

Monsant, A.C.; Kappen, P.; Wang, Y.D.; Pigram, P.J.; Baker, A.J.M.; Tang, C.X. 2011. In vivo speciation of zinc in Noccaea caerulescens in response to nitrogen form and zinc exposure. Plant and Soil 348: 167-183.

Monteiro, C.C.; Carvalho, R.F.; Gratão, P.L.; Carvalho, G.; Tezotto, T.; Medici, L.O.; Peres, L.E.P.; Azevedo, R.A. 2011. Biochemical responses of the ethylene-insensitive Never ripe tomato mutant subjected to cadmium and sodium stresses. Environmental and Experimental Botany 71: 306-320.

Obbard, J.P.; Jones, K.C. 2001. Measurement of symbiotic nitrogen-fixation in leguminous host-plants grown in heavy metal-contaminated soils amended with sewage sludge. Environmental Pollution 111: 311-320.

Pereira, B.F.F.; de Abreu, C.A.; Herpin, U.; de Abreu, M.F.; Berton, R.S. 2010. Phytoremediation of lead by jack beans on a Rhodic Hapludox amended with EDTA. Scientia Agricola 67: 308-318.

Peuke, A.D.; Rennenberg, H. 2005. Phytoremediation: Molecular biology, requirements for application, environmental protection, public attention and feasibility. European Molecular Biology Organization 6: 497-501.

Pilon-Smits, E. 2005. Phytoremediation. Annual Review of Plant Biology 56: 15-39.

Qin, F.; Shan, X.Q.; Wei, B. 2004. Effects of low-molecular-weight organic acids and residence time on desorption of $\mathrm{Cu}, \mathrm{Cd}$, and $\mathrm{Pb}$ from soils. Chemosphere 57: 253-263.

Quartacci, M.F.; Baker, A.J.M.; Navari-Izzo, F. 2005. Nitrilotriacetate- and citric acid-assisted phytoextraction of cadmium by Indian mustard (Brassica juncea (L.) Czernj, Brassicaceae). Chemosphere 59: 1249-1255.

Quartacci, M.F.; Irtelli, B.; Baker, A.J.M.; Navari-Izzo, F. 2007. The use of NTA and EDDS for enhanced phytoextraction of metals from multiply contaminated soil by Brassica carinata. Chemosphere 68: 1920-1928.
Reichman, S.M. 2007. The potential use of the legume-rhizobium symbiosis for the remediation of arsenic contaminated sites. Soil Biology and Biochemistry 39: 2587-2593.

Salt, D.E.; Smith, R.D.; Raskin, I. 1998. Phytoremediation. Annual Review of Plant Physiology and Plant Molecular Biology 49: 643-668.

Sarret, G.; Saumitou-Laprade, P.; Bert, V.; Proux, O.; Hazemann, J.L.; Traverse, A.S.; Marcus, M.A.; Manceau, A. 2002. Forms of zinc accumulated in the hyperaccumulator Arabidopsis halleri. Plant Physiology 130: 1815-1826.

Sauerbeck, D.R. 1991. Plant, element and soil properties governing uptake and availability of heavy metals derived from sewage sludge. Water Air and Soil Pollution 57-8: 227-237.

Seth, C.S.; Misra, V.; Singh, R.R.; Zolla, L. 2011. EDTA-enhanced lead phytoremediation in sunflower (Helianthus annuus L.) hydroponic culture. Plant and Soil 347: 231-242.

Smith, S.R. 2009. A critical review of the bioavailability and impacts of heavy metals in municipal solid waste composts compared to sewage sludge. Environment International 35: 142-156.

Sun, R.L.; Zhou, Q.X.; Jin, C.X. 2006. Cadmium accumulation in relation to organic acids in leaves of Solanum nigrum L. as a newly found cadmium hyperaccumulator. Plant and Soil 285: 125-134.

Ullah, R.; Bakht, J.; Shafi, M.; Iqbal, M.; Khan, A.; Saeed, M. 2011. Phyto-accumulation of heavy metals by sunflower (Helianthus annuus L.) grown on contaminated soil. African Journal of Biotechnology 10: 17192-17198.

Yamamoto, F.; Kozlowski, T.T. 1987. Effect of flooding, tilting of stems, and ethrel application on growth, stem anatomy, and ethylene production of Acer platanoides seedlings. Scandinavian Journal of Forest Research 2: 141-156.

Zacchini, M.; Pietrini, F.; Mugnozza, G.S.; Iori, V.; Pietrosanti, L.; Massacci, A. 2009. Metal tolerance, accumulation and translocation in poplar and willow clones treated with cadmium in hydroponics. Water Air and Soil Pollution 197: 23-34.

Zhu, Y.; Bi, D.; Yuan, L.; Yin, X. 2012. Phytoremediation of cadmium and copper contaminated soils. p. 75-81. In: Yin, X.; Yuan, L., eds. Phytoremediation and biofortification: two sides of one coin. Springer, New York, NY, USA. 